IOSR Journal of Engineering

e-ISSN: 2250-3021, p-ISSN: 2278-8719,

Vol. 2, Issue 12 (Dec. 2012) ||V2|| PP 34-40

\title{
Performance of Details in Connection of Precast Concrete
}

\author{
Naser Faraj Bankashen ${ }^{1}$, Sri Murni Dewi ${ }^{2}$, Achfas Zacoeb ${ }^{3}$ \\ ${ }^{I}$ (M. Eng. Student, Departmentof CivilEngineering, BrawijayaUniversity, Indonesia) \\ ${ }^{2}$ (Professor, Departmentof CivilEngineering, BrawijayaUniversity, Indonesia) \\ ${ }^{3}$ (Asst. Professor, Departmentof CivilEngineering, BrawijayaUniversity, Indonesia)
}

\begin{abstract}
The aim of this paper is to carry out an experimental investigation on different types of precast reinforcement connection. Minutely, Type1 is a welded plate where the plate joins the bars extended to meet the requirements. Type 2 is welded bars connection where the bars extended to overlap then be welded together. The understanding of connection behavior is important and can only be assessed by conducting experimental test. Therefore, the objectives of this experiment are to study the behavior of precast joint, strain behavior, and crack pattern, and to identify the most suitable types of connection to be introduced to industry. On this premise, six precast simple beams, and six precast beam-column connections with sectional plan $150 \mathrm{~mm}$ x $150 \mathrm{~mm}$ with span $1200 \mathrm{~mm}$ for simple beam and $750 \mathrm{~mm}$ for span of B-C connection, and the inverse U-shape with thickness $50 \mathrm{~mm}$. All specimens were tested under static load. The result shows that the comparison of the experimental result and theoretical analysis converges quite well in maximum load. On the other hand, the comparison between welded bars and welded plates show that there are no significant influences.
\end{abstract}

Keywords:- B-C connection, precast connection, precast concrete, welded plate, welded bars.

\section{INTRODUCTION}

Precast concrete structures are very popular in Libya and North Africa because of many adantages such as low construction cost, high member quality and construction speed,better architectural modularity and climate independent projectscheduling. To validate theseitems and expand the market of precast concrete structure,assembling or connection process becomes very important. Therefore, connector conceptsneed to be identified as Avoiding extensive welding, Incorporating adequate tolerances, Avoiding large formed wet joints, Designing joints that minimize crane time.

The percentage of the precast concrete frame type structures, in the field of industrial construction such as factory buildings and warehousing, is dominantly high in Libya as compared to the cast-in-place reinforced concrete or steel structures. On the other hand, two or more story precast concrete shopping malls, school buildings,dormitories, residential buildings, office spaces and parking lots are rare or none[1].

Performance and damage level of such structures are mainly determined by the capacity and ductile performance of the connections [2]. The premature failure of such connections prevents the ductile behavior of the adjoining members and the overall load carrying frame system.

Compared to conventional cast-in-site reinforced concrete constructions, precast concrete methods have shown significant advantages such as:

- Depending on the investment at precast plant or factory and the nature of the projects, theusage of precast concrete will usually lower the overall construction cost especially through material costs saving in formwork and shutter fabrications for large projects. Thecosts for formwork and scaffolding in cast-in-site reinforced concrete constructions could be as high as one third of the overall project costs. The moulds and formwork used [3] for prefabrication of precast concrete components at precast plants are properly designed to be made from plastic-timber or metal which if properly used can last up to more than hundreds of casting cycles

- The casting and curing of precast concrete elements in shutter factory under controlled environment and conditions have ruled out the influence of bad weather in disturbing work progress. Besides, the controlled environment and application of most appropriate curing method will improve concrete hardening progress as well as produce higher quality products [3].

- The mass production of standardized precast concrete components has optimized the laborsskill and cost, hence increasing the productivity

- Lesser wet works are required to be carried out at sites with the reducing in the usage of in-site concrete, mortar or grout, hence making the sites cleaner and dryer. Only some simpler wet works such as mortar plastering or grouting are required when joining the precast elements, comparing to the pouring of tons of wet concrete slurry in the Cast-in-site works, [3]. 
- An actual case study and analysis comparing the design of a block of flats between the in-site monolithic building method and the precast unit construction had concluded that the precast unit construction would require only 954 tons of materials comparing to the 2468 tons required in monolithic construction, which meant the precast unit was able to save up to $70 \%$ of material wastages[2]. In a separate study[4], revealed that prefabrication construction method could reduce tremendously the volume of material wastages compared to conventional building technique.

\section{METHODOLOGY}

\section{A. The Study Design}

The design of research studies on beam-column connection and beam reinforcement connection. This study is included in experimental research. The analysis carried out is:

1. Theoretical analysis using a cross section of elastic theory to calculate the load that leads to crack initiation, and the boundary force method to determine the maximum load that can hold beam-column connection. The result of this theoretical analysis will be compared with experimental test results.

2. Data analysis of test results from the testing of technical data of the beam-column connection and beam reinforcement connection will obtain load-deflection relationship, the load at crack initiation and maximum load.

\section{B. Test setting up}

Test Objects bend on beams with connection on reinforcement. The simple beam is supported with panned support at both ends. The load given in the form of concentrated load $\mathrm{P}$ span is divided into two points, each one with a $0.5 \mathrm{P}$ and distance between two is $35 \mathrm{~cm}$. The dial gauge is installed at the bottom, just below the load point. The supports are fixed $5 \mathrm{~cm}$ from the edge of span in both sides, so the effective span is $110 \mathrm{~cm}$ long. Setting up specimen on test machine can be seen in Fig.1.

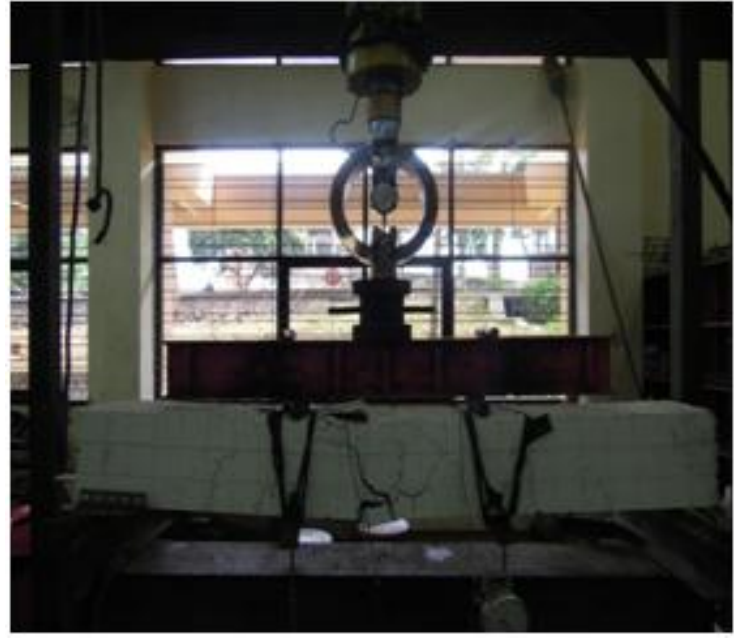

Fig.1 setting up precast simple beam specimen on test machine

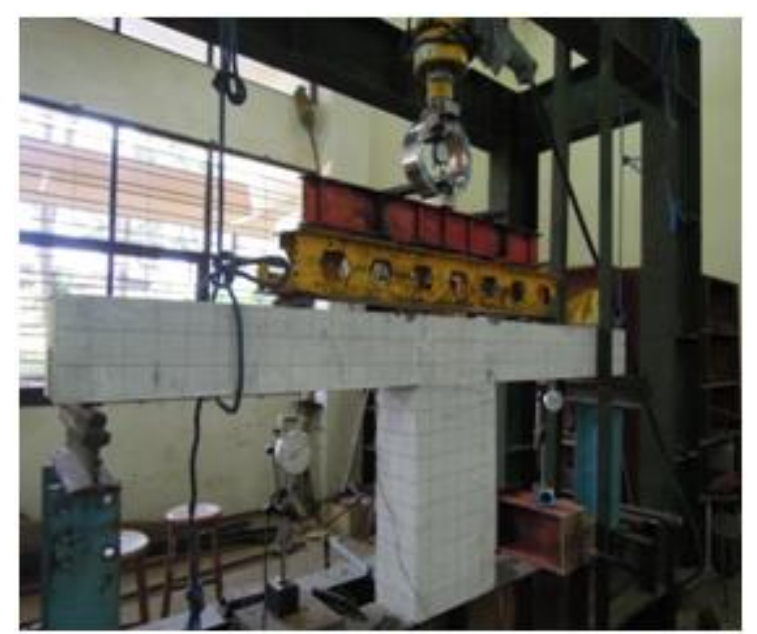

Fig 2 setting up precast beam-column connection on test machine

III.

\section{DISSCUSION OF RESULT}

\section{A. Testing of simple beam}

Based on the simple beam, flexural testing was done by providing a concentrated load $\mathrm{P}$ which was divided into two points at 1/2P Fig1. The loading stages used one strip (each strip equal to $134 \mathrm{Kg}$ ) on the proving ring with the capacity of 25 tons, starting from zero to achieve maximum load of beam.

The data from the testing included the first crack load, maximum load, deflection load, and the pattern of crack that occured. Load was obtained from the readings of proving ring, deflection was obtained from the reading of dial gauge, whereas crack pattern was obtained from observation by visual way on the beam.

From the TABLE2shows that the relative error between experimental result and theoretical analysis, in the load that caused first cracking in the early visual observations on SB-1W is51.9 and on SB-2W is55.1, while the relative error of deflection at the same load is $63.9 \mathrm{on}$ SB-1W and $73.5 \mathrm{on} \mathrm{SB}-2 \mathrm{~W}$. The relative error of the maximum load from test result and theoretical analysis that can hold SB-1W is 1.9 and SB-2W is 1.4. Maximum deflection's relative error in the test result and theoretical analysis on SB-1W is 2.7 and SB-2W is 4.1 . In additional, From the TABLE2 it is clear that the relative error between the experimental result and theoretical analysis in welded bars at simple beam, the load that caused first cracking in the early visual observations on SB-1P, SB-2P and SB-3P.SG are 51.9, 38.8 and 51.9 respectively, while the relative error of deflection at the 
same load are 90.9,88.7 and 86.3. On the other hand, the relative error of the maximum load from test result and theoretical analysis that can hold is 37.6 at the three specimens. Also the relative error at maximum deflection in SB-1P is 65.8, at SB-2P is 60.4 and SB-3P.SG is 68.8 .

TABLE 1 : The comparison of the experiment result between SB-W and SB-P

\begin{tabular}{|c|c|c|c|}
\hline Condition & SB-W & SB-P & $\begin{array}{c}\text { Relative } \\
\text { error \% }\end{array}$ \\
\hline $\begin{array}{c}\text { Load at } \\
\text { first } \\
\text { crack(kg) }\end{array}$ & 1943 & 1742 & 11.5 \\
\hline $\begin{array}{c}\text { Deflection } \\
\text { at first } \\
\text { crack } \\
\text { (mm) }\end{array}$ & 0.705 & 1.95 & 63.8 \\
\hline $\begin{array}{c}\text { Maximum } \\
\text { load (kg) }\end{array}$ & 7772 & 5717 & 35.1 \\
\hline $\begin{array}{c}\text { Maximum } \\
\text { deflection } \\
\text { (mm) }\end{array}$ & 3.63 & 10.4 & 65. \\
\hline
\end{tabular}

From the comparison in the TABLE 1 it can be seen that the first flexural crack from visual observation occurs at $1943 \mathrm{~kg}$ in the specimen SB-W and $1742 \mathrm{~kg}$ in the specimen SB-P. However, the deflection at the same point of load is $0.705 \mathrm{~mm}$ on SB-W and $1.95 \mathrm{~mm}$ on SB-P. The main reason for the difference in displacement is the development of reinforcement connection. Moreover, the maximum load in the two types of specimens is $7772 \mathrm{~kg}$ and $5717 \mathrm{~kg}$ for SB-W and SB-P respectively.

\section{B. Testing on Beam-Column Connection}

For this test, two beams were connected with a column. There were two groups of specimens in which each group consisted of three test objects.

Loading was done by providing a concentrated P's load which was divided into two points at $1 / 2 \mathrm{P}$. Loading stagesused one strip (equivalent to $134 \mathrm{~kg}$ ) on a scale of proving ring readings. The loading started from zero load to achieve the maximum load of B-C connection.

Testing was conducted to determine the effect of two types of reinforcement connection used to connect two beams with the column of the first cracking load, maximum load, deflection, and pattern collapse (cracks) that occured due to a given load.

The data of the test were obtained in the form of the first crack, maximum load, deflection and cracks pattern that occured. The load was recorded by the reading the proving ring, deflection was obtained from the dial gauge's reading, while the crack pattern was obtained from visual observations at the beam-column connection.

TheTABLE 3illustrates that the relative error between the result of research and theoretical connection analysis in the B-C connection for load that caused first crack by visual observation on SB-C_1W.SG is 2.09, SB-C_2W is 28.8 and SB-C_3W is 24.3. At the same condition of load which caused first crack, the deflection's relative error in SB-C_1W.SG is 34.1, SB-C_2W is 175 and SB-C_3P is 263. On the maximum load and maximum deflection there is no relative error calculated because the load did not reach the ultimatecapacity.

On the B-C connection with welded plate the TABLE 3 reveals that the relative error between the result of research and theoretical connection analysis in the B-C connection for load that caused first crack by visual observation on SB-C_1P.SG is 49.8; SB-C_2P is 60.5 and SB-C_3P is 60.5. The relative error for the deflection occurred on the load that caused crack initiation on SB-C_1P.SGis 64.2; SB-C_2Pis 65.6 and SB-C_3P is 63.7.

\section{Pattern of Crack}

The pattern of crack on simple beam and B-C connection can be seen from the pattern of cracks that occurred.The initial crack occured due to the collapse of the tensile region, the cracks occurred at the edge of beam experiencing tensile stress, and its direction was almost perpendicular to the axis of 
TABLE2The comparison results between theoretical analysis and experimental result in simple beam with welded plate (SB-P) and welded bars (SB-W)

\begin{tabular}{|c|c|c|c|c|c|c|c|c|}
\hline Condition & $\begin{array}{l}\text { Theoretical } \\
\text { analysis }\end{array}$ & $\begin{array}{l}\text { Experime } \\
\text { ntal result }\end{array}$ & $\begin{array}{l}\text { Relative } \\
\text { error \% }\end{array}$ & $\begin{array}{l}\text { specime } \\
\text { ns }\end{array}$ & $\begin{array}{c}\text { Theoret } \\
\text { ical } \\
\text { analysis }\end{array}$ & $\begin{array}{l}\text { Experimen } \\
\text { tal result }\end{array}$ & $\begin{array}{c}\text { Rela } \\
\text { tive } \\
\text { error } \\
\%\end{array}$ & $\begin{array}{c}\text { Specime } \\
\mathrm{n}\end{array}$ \\
\hline $\begin{array}{l}\text { Load at first } \\
\text { crack }(\mathrm{kg})\end{array}$ & 901.2 & 1876 & 51.9 & \multirow{4}{*}{ SB-1P } & 901.2 & 1876 & 51.9 & \multirow{4}{*}{ SB-1W } \\
\hline $\begin{array}{l}\text { Deflection at first } \\
\text { crack }(\mathrm{mm})\end{array}$ & 0.215 & 2.38 & 90.9 & & 0.215 & 0.597 & 63.9 & \\
\hline Maximum load (kg) & 7749.2 & 5628 & 37.6 & & 7749.2 & 7906 & 1.9 & \\
\hline $\begin{array}{l}\text { Maximum } \\
\text { deflection }(\mathrm{mm})\end{array}$ & 3.601 & 10.54 & 65.8 & & 3.601 & 3.505 & 2.7 & \\
\hline $\begin{array}{l}\text { Load at first } \\
\text { crack }(\mathrm{kg})\end{array}$ & 901.2 & 1474 & 38.8 & \multirow{4}{*}{ SB-2P } & 901.2 & 2010 & 55.1 & \multirow{4}{*}{ SB-2W } \\
\hline $\begin{array}{l}\text { Deflection at first } \\
\operatorname{crack}(\mathrm{mm})\end{array}$ & 0.215 & 1.91 & 88.7 & & 0.215 & 0.814 & 73.5 & \\
\hline Maximum load (kg) & 7749.2 & 5628 & 37.6 & & 7749.2 & 7638 & 1.45 & \\
\hline $\begin{array}{l}\text { Maximum } \\
\text { deflection(mm) }\end{array}$ & 3.601 & 9.1 & 60.4 & & 3.601 & 3.755 & 4.1 & \\
\hline $\begin{array}{l}\text { Load at first } \\
\operatorname{crack}(\mathrm{kg})\end{array}$ & 901.2 & 1876 & 51.9 & \multirow{4}{*}{$\begin{array}{l}\text { SB- } \\
\text { 3P.SG }\end{array}$} & & & & \\
\hline $\begin{array}{l}\text { Deflection at first } \\
\operatorname{crack}(\mathrm{mm})\end{array}$ & 0.215 & 1.57 & 86.3 & & & & & \\
\hline Maximum load (kg) & 7749.2 & 5628 & 37.6 & & & & & \\
\hline $\begin{array}{l}\text { Maximum } \\
\text { deflection }(\mathrm{mm})\end{array}$ & 3.601 & 11.57 & 68.8 & & & & & \\
\hline
\end{tabular}

TABLE 3 comparison results between theoretical analysis and experimental result in B-C connection with welded bars (SB-C_W) and welded plate (SB-C_P)

\begin{tabular}{|c|c|c|c|c|c|c|c|c|}
\hline Condition & $\begin{array}{c}\text { Theoretic } \\
\text { al } \\
\text { analysis }\end{array}$ & $\begin{array}{l}\text { Experiment } \\
\text { al result }\end{array}$ & $\begin{array}{l}\text { Relative } \\
\text { error } \%\end{array}$ & $\begin{array}{l}\text { Specim } \\
\text { ens }\end{array}$ & $\begin{array}{l}\text { Theoreti } \\
\text { cal } \\
\text { analysis }\end{array}$ & $\begin{array}{l}\text { Experime } \\
\text { ntal result }\end{array}$ & $\begin{array}{l}\text { Relati } \\
\text { ve } \\
\text { error } \\
\%\end{array}$ & Specimens \\
\hline $\begin{array}{l}\text { Load at first } \\
\text { crack }(\mathrm{kg})\end{array}$ & 3,011 & 2,948 & 2.13 & \multirow{4}{*}{$\begin{array}{l}\mathrm{SB}- \\
\mathrm{C}_{-} 1 \mathrm{~W} . \mathrm{S} \\
\mathrm{G}\end{array}$} & 3,011 & 2,010 & 49.8 & \multirow{4}{*}{$\begin{array}{c}\text { SB- } \\
\text { C_1P.SG }\end{array}$} \\
\hline $\begin{array}{l}\text { Deflection at first } \\
\text { crack }(\mathrm{mm})\end{array}$ & 0.261 & 0.35 & 25.4 & & 0.261 & 0.73 & 64.2 & \\
\hline Maximum load (kg) & 26,545 & 10,988 & - & & 26,545 & 10,988 & - & \\
\hline $\begin{array}{l}\text { Maximum } \\
\text { deflection }(\mathrm{mm})\end{array}$ & 4.494 & 2.12 & - & & 4.494 & 2.19 & - & \\
\hline $\begin{array}{l}\text { Load at first } \\
\text { crack }(\mathrm{kg})\end{array}$ & 3,011 & 2,144 & 40.4 & \multirow{4}{*}{$\begin{array}{l}\mathrm{SB}- \\
\mathrm{C} \_2 \mathrm{~W}\end{array}$} & 3,011 & 1,876 & 60.5 & \multirow{4}{*}{ SB-C_2P } \\
\hline $\begin{array}{l}\text { Deflection at first } \\
\text { crack }(\mathrm{mm})\end{array}$ & 0.261 & 0.72 & 63.7 & & 0.261 & 0.76 & 65.6 & \\
\hline Maximum load (kg) & 26,545 & 9,514 & - & & 26,545 & 10,988 & - & \\
\hline $\begin{array}{l}\text { Maximum } \\
\text { deflection }(\mathrm{mm})\end{array}$ & 4.494 & 2.52 & - & & 4.494 & 2.37 & - & \\
\hline $\begin{array}{l}\text { Load at first } \\
\text { crack }(\mathrm{kg})\end{array}$ & 3,011 & 2,278 & 63.7 & \multirow{4}{*}{$\begin{array}{l}\text { SB- } \\
\text { C_3W }\end{array}$} & 3,011 & 1,876 & 60.5 & \multirow{4}{*}{ SB-C_3P } \\
\hline $\begin{array}{l}\text { Deflection at first } \\
\text { crack }(\mathrm{mm})\end{array}$ & 0.261 & 0.95 & 72.5 & & 0.261 & 0.72 & 63.7 & \\
\hline Maximum load (kg) & 26,545 & 8442 & - & & 26,545 & 10,988 & - & \\
\hline $\begin{array}{l}\text { Maximum } \\
\text { deflection }(\mathrm{mm})\end{array}$ & 4.494 & 2.58 & - & & 4.494 & 2.37 & - & \\
\hline
\end{tabular}

the beam. Cracking that occured is called the flexural cracks. 
With the addition of load, the crack propagated upward and then turned toward the diagonal, this occured because the diagonal tensile stress in the region above the crack exceeded the tensile strength of concrete. These cracks are called flexural-shear cracks. After it happened, the beam collapsed at the maximum load.

\section{Testing the strain in the reinforcement ofSimple beam and B-C connection}

Strain on connective simple beam and B-C reinforcement can be measured by using strain-gauge steel to represent thespecimens of B-C connections.. In particular, strain gauge is fixed at two points of the left and right bars next to both sides of the welded position.

Readings were taken at intervals corresponding to the $134 \mathrm{~kg}$ weight increase in one strip on a scale of proving ring readings. The relation between the load-strain can be determined by the reading.Chart of load and strain in SB-C_1W.SG and SB-C_1P.SG can be seen on the Fig 5 and Fig 6.

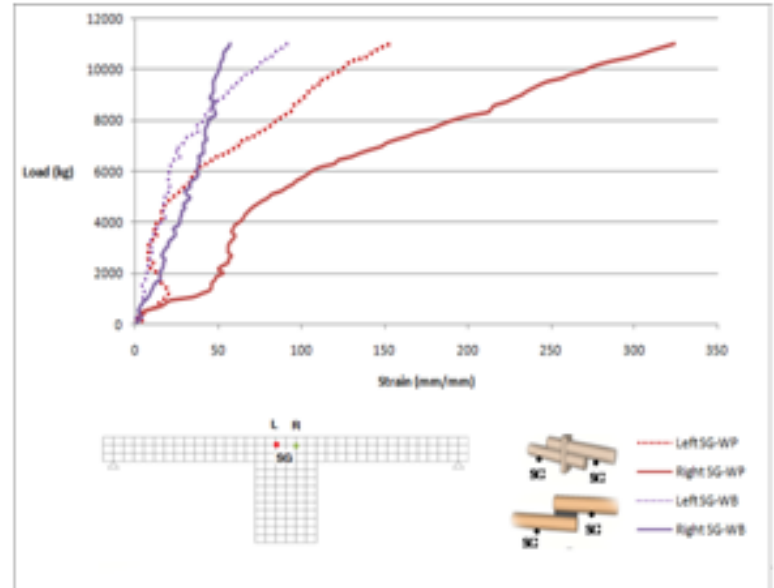

Fig 5 the relation of Load-Strain for B-Cconnection in (SB-C_W) and (SB-C_P)

From the chat above can be seen that at welded bars strain, the trend in both left and right strain have fluctuated curve. However, the two curves were close until the load reaches 8.2 tons. After that they crossed to have steady increase until maximum load to reach $(45$ and $75 \mathrm{~mm} / \mathrm{mm})$ for the right and left respectively. On the other hand, the welded plate's curves have same trend of increasing to reach a peak at $125 \mathrm{~mm} / \mathrm{mm}$ for the left SG and 325 for the right SG. The comparison between the welded bars and welded plate shows that the welded plate stronger than welded bars.

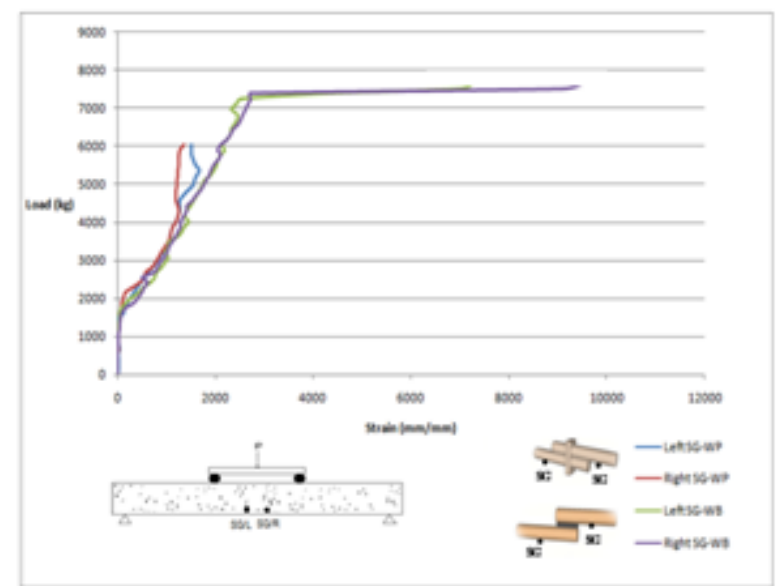

Fig. 6 the relation of Load-Strain for beam in (SB-WP) and (SB-WB)

From the chart above,it is evident that the trend in welded bars strainboth left and right strain approximately the same. However, at 6000kg the strain was 1500 at the left SG, and 1348 at right SG. Secondly, the welded plate's curves have the same trend of increasing, to reach a peak $9500(\mathrm{~mm} / \mathrm{mm})$ at left $S G$ and $7700(\mathrm{~mm} / \mathrm{mm})$ at right SG. Overall, it can be seen that the strain in welded plate specimen is lower than welded bars specimen when subjected to same load. Moreover, the highest point which the strain reached by welded bars strain was $9415 \mathrm{~mm} / \mathrm{mm}$. 


\section{Statistic Analysis}

The investigation of the influence of variations on the type of connection and moments is performed in the statistical analysis in the form of multi-range.

TABLE4 : Analysis of Variance for a Randomized Complete Block Design at maximum load

\begin{tabular}{|c|c|c|c|c|c|}
\hline $\begin{array}{c}\text { Source of } \\
\text { variation }\end{array}$ & $\begin{array}{c}\text { Sum of } \\
\text { squares }\end{array}$ & $\begin{array}{c}\text { Dagree } \\
\text { of } \\
\text { freedom }\end{array}$ & $\begin{array}{c}\text { Mean } \\
\text { square }\end{array}$ & $F_{0}$ & $\begin{array}{c}\text { Ft } \\
\text { table }\end{array}$ \\
\hline $\begin{array}{c}\text { Treatment } \\
\text { A }\end{array}$ & $49,030,662$ & 1 & $49,030,662$ & 0.23 & \\
\hline $\begin{array}{c}\text { Treatment } \\
\text { B }\end{array}$ & $54,859,208$ & 1 & $54,859,208$ & 0.29 & \multirow{2}{*}{7,71} \\
\hline Interaction & $51,583,020$ & 1 & $51,583,020$ & 0.27 & \\
\hline Error & $674,435,354$ & 4 & $186,608,839$ & & \\
\hline Total & 829908244 & 7 & & & \\
\hline
\end{tabular}

From the table above it can be seen that the significant level obtained by F-table is 7.71, While F-count shows the variation of connection and moments. Therefore, it can be concluded that the connection type and moments of these two variables do not have a significant influence on the maximum load.

\section{CONCLUSION}

From the exposure of the data analysis, results can be concluded as follows:

The maximum average load that can be held by a simple precast beam is $7772 \mathrm{~kg}$ for welded bars specimen and $5717 \mathrm{~kg}$ for welded plate specimen, while the average maximum deflection that occurred on both specimens are $3.63 \mathrm{~mm}$ and $10.4 \mathrm{~mm}$ for welded bars and welded plate respectively. On the other hand, The maximum average load applied to the B-C connection was $10988 \mathrm{~kg}$ for welded bars and $9648 \mathrm{~kg}$ for welded plate. Moreover, the maximum deflection reached is $2.61 \mathrm{~mm}$ for welded bars and $2.4 \mathrm{~mm}$ for welded plate. At maximum load reached by the test machine, there is no significant effect in the welded plate and welded bars because the load did not reach the maximum. Reinforcement strain on the simple beam and B-C connection shows that the significant influences were in comparison between welded bars and welded plate at simple beam. So the stronger connection was the welded plate in positive moment. Otherwise, in B-C connection the welded bars were stronger at the highest load applied.Variations in the connection details at simple beam and B-C connection do not have a significant influence at maximum load and maximum deflection.

\section{Suggestions}

Based on the research presented in this thesis, the following topics are considered to be promising directions for further research:

1. Implementation of the manufacture and testing of the specimen (specimen mounting and installation of measuring devices) need to be looked at more carefully to avoid the mistakes that lead to deviations between the results of research and theoretical analysis.

2. Controls require additional deflection points to know the behavior of the structure studied in detail, especially on the parts put in the cast at different times and joints.

3. The research can be developed in connection to the model to know the kind of connection most effectively and efficiently, given the connection is a major problem in precast concrete.

4. Research on B-C connection can be developed by examining the connection between the joints.

5. Analysing the same connection in a 3 dimensional models and comparing the results with those from this investigation would be valuable.

6. Modelling and designing another promising solution of a ductile connection and comparing it with the results of this investigation would also be appealing.

\section{REFERENCES}

1). Lee, Ju, and Syu, "Alternative Details for Bottom Beam Bars Terminated in a Column-Experimental Investigation”," ACI Structural Journal, 2009.

2). Glover, C.W., 1964." Structural Precast Concrete”, 1st Edn., CR Books Limited, London, pp: 664.

3). Yee, Bin Adnan, Mirasa and Abdul Rahman "Performance of IBS Precast Concrete Beam-Column Connections Under Earthquake Effects" A Literature Review. Department of Structures and Materials, Faculty of Civil Engineering,UTM, Malaysia, 2010. 
4). Begum, R.A., S.K. Satari and J.J. Pereira, 2010: Waste generation and recycling: Comparison of conventional and industrialized building systems.

5). American Concrete Institute, (ACI 318-11, 2011): Building Code Requirement for Structural Concrete and Commentary. ACI Committee 318, 2011.

6). American Concrete Institute, (ACI 550R-96): Design Recommendations for Precast Concrete Structures, ACI committee 318,1996.

7). Elias Issa Saqan, 1995. "Evaluation of Ductile Beam-Column Connection for use in Seismic-Resistant Precast Frame” Doctor of Philosophy, The University of Texas at Austin.

8). Ilenka, 2011. "Sloof of bamboo composite precast". Master thesis, University of Brawijaya, Malang (Indonesia).

9). G. Nawy, 2003. “Reinforcement Concrete A fundamental Approch” fifth edition. The state University of New Jersey.

10). Sri Murni Dewi, Ludfi Djakfar. 2011, ’Statistika Dasar, Edisi 2"'Malang, Indonesia. 